\title{
A Mannose Receptor Mediates Mannosyl-rich Glycoprotein-induced Mitogenesis in Bovine Airway Smooth Muscle Cells
}

\author{
D. Betty Lew, Emel Songu-Mize, ${ }^{\ddagger}$ Suzanne E. Pontow, ${ }^{\mathbf{5}}$ Philip D. Stahl, ${ }^{\mathbf{5}}$ and Mario C. Rattazzi" \\ Crippled Children's Foundation Research Center at LeBonheur Children's Medical Center, * Department of Pediatrics and ${ }^{\ddagger}$ Department \\ of Pharmacology, University of Tennessee, Memphis, Tennessee $38163 ;{ }^{\S}$ Department of Cell Biology and Physiology, Washington \\ University School of Medicine, St. Louis, Missouri 63110; and "Department of Human Genetics, Mount Sinai School of Medicine, \\ New York 10029
}

\begin{abstract}
The putative mannose receptor (MR), previously implicated in mannosyl-rich glycoprotein-induced mitogenesis in bovine airway smooth muscle (ASM) cells, was studied to determine its properties. Specific binding of the mitogenic neoglycoprotein, mannosylated bovine serum albumin (ManBSA) to ASM cells was saturable, with an apparent $K_{\mathrm{d}}=\mathbf{5 . 0}$ $\times 10^{-8} \mathrm{M}$. Cell-bound ManBSA-colloidal gold conjugate was localized by electron microscopy to clathrin-coated pits on the cell surface, and was found to undergo internalization to endosomes; this was inhibitable by weak bases and swainsonine, that also inhibited ligand-induced mitogenesis. The ASM-MR, isolated by mannose-affinity chromatography, had the same apparent molecular mass as the macrophage (Mø) MR $\left(M_{\mathrm{r}}=175 \mathrm{kD}\right)$, and was immunoprecipitated by an anti-MøMR immune serum. This antiserum blocked ${ }^{125} \mathrm{I}$ labeled-ManBSA binding to intact ASM cells, stimulated mitogenesis, and immunolocalized the ASM-MR in cytoplasmic vesicles compatible with endosomes. A monoclonal antibody directed against the MøMR also reacted with the ASM-MR; like the polyclonal antibodies, it stimulated mitogenesis as effectively as $\beta$-hexosaminidases. These data indicate that the ASM-MR shares a number of functional and structural properties with the MøMR and suggest that similar receptors may have different main functions in different cells. (J. Clin. Invest. 1994. 94:1855-1863.) Key words: airway smooth muscle - proliferation - agonistic antibodies • lysosomal hydrolases • asthma
\end{abstract}

E. Songu-Mize's present address is Department of Pharmacology and Experimental Therapeutics, Louisiana State University Medical Center, New Orleans, LA 70112.

Address correspondence to D. Betty Lew, M.D., University of Tennessee, Crippled Children's Foundation Research Center, 50 N. Dunlap St., Rm. 401, Memphis, TN 38103.

Received for publication 29 November 1993 and in revised form 1 July 1994.

1. Abbreviations used in this paper: ASM, airway smooth muscle; CQ, chloroquine; G-protein, guanine nucleotide triphosphate-binding protein; Hex, $\beta$-hexosaminidase; hGH, human growth hormone; MA, methylamine; ManBSA, mannose-bovine serum albumin; ManGP, mannosyl-rich glycoprotein; Mø, macrophage; MR, mannose receptor; $\mathrm{PLA}_{2}$, phospholipase $\mathrm{A}_{2} ; \mathrm{SW}$, swainsonine; THR, thyrotropin receptor.

J. Clin. Invest.

(C) The American Society for Clinical Investigation, Inc. 0021-9738/94/11/1855/09 \$2.00

Volume 94, November 1994, 1855-1863

\section{Introduction}

Airway smooth muscle (ASM) ${ }^{1}$ hyperplasia/hypertrophy is an important pathological finding that may be closely related to airway hyperreactivity in asthma (1-3). During an acute asthma attack, the activity of several lysosomal hydrolases is increased significantly in brochoalveolar lavage fluid in allergic human subjects $(4,5)$ and in an animal model of ozone-induced airway hyperreactivity (6). Furthermore, lysosomal hydrolases such as human $\beta$-hexosaminidase (Hex) and bovine $\beta$-glucuronidase promote mitogenesis of bovine ASM cells (7). We have hypothesized that lysosomal enzymes released by inflammatory cells in the airways, by promoting proliferation of ASM cells, contribute to hypertrophy/hyperplasia of ASM (7). As we have shown, other mannosyl-rich glycoproteins (ManGP), such as mannose-bovine serum albumin (ManBSA) and $\mathrm{Man}_{3}-\mathrm{N}$-acetylglucosamine-HSA, have mitogenic activity in ASM cells (7).

The mitogenic effect is blocked by yeast mannan, a mannose receptor (MR) blocker (8), but not by mannose-6-phosphate, a specific blocker of the cation independent mannose-6-phosphate/insulin-like growth factor II receptor (9), suggesting the involvement of a mannose-recognizing moiety (7).

The well-studied mannose receptor of macrophages (MøMR) is involved in receptor-mediated endocytosis and molecular scavenging of ManGP as well as phagocytosis and host defense against mannosyl-rich pathogens (10-12). Mannosylrich enzymes such as lysosomal hydrolases including Hex (11), myeloperoxidase (13), and plasminogen activator (14) are also taken up by MR that has been found in liver reticuloendothelial (Kupffer) cells (15-17), mononuclear phagocytes (18), retinal pigment epithelium (19), placenta (20), and recently in lymphoid dendritic cells (21). However, it is not known whether MR is expressed in ASM. Moreover, a trophic function, i.e., promotion of mitogenesis, is not a known characteristic of MR. The objectives of this study were to characterize the ASM cellputative MR; to confirm that a mannose-recognizing receptor moiety mediates ManGP-induced mitogenesis in ASM cells; and to establish its relationship, if any, with MøMR.

\section{Methods}

Airway smooth muscle culture. Primary cultures of bovine ASM cells were prepared from bovine trachealis muscle by a modification of the method of Kotlikoff et al. (22) as described previously (7). Direct immunofluorescence staining of the cells with a FITC-conjugated $\mathrm{mAb}$ against smooth muscle isoactin (Sigma Chemical Co., St. Louis, MO) demonstrated that cultures consisted of a homogenous population of smooth muscle cells (7). Cells at passages 1-7 were used for experiments.

Assessment of proliferation. DNA synthesis rates were assessed by measuring $\left[{ }^{3} \mathrm{H}\right]$ thymidine incorporation. Confluent cells in T-75 flasks were detached by trypsinization $(0.12 \%$ for $5-7 \mathrm{~min})$ and were treated 
with appropriate amounts of soybean trypsin inhibitor (Sigma Chemical Co.). Cells were then plated $\left(2.5 \times 10^{4}\right.$ cells/well $)$ in 96-well flat-bottom microtiter plates (Linbro; Flow Laboratories, Inc., McLean, VA) in M199 containing 10\% (vol/vol) FBS; $72 \mathrm{~h}$ later, after the cells reached confluence and were contact-inhibited, the medium was replaced with M199 containing $0.4 \%$ (vol/vol) FBS $48 \mathrm{~h}$ before exposure to test substances. $\left[{ }^{3} \mathrm{H}\right]$ Thymidine $(0.5 \mu \mathrm{Ci} /$ well, sp act $10 \mathrm{Ci} / \mathrm{mmol}$; Amersham Corp., Arlington Heights, IL) was added to cells $24 \mathrm{~h}$ after the addition of test substances, and cells were harvested $18 \mathrm{~h}$ later as described by Dohlman et al. (23). Radioactivity was quantified in a liquid scintillation counter (2000 CA; Packard Instrument Co., Inc., Meriden, CT).

In some experiments, cells were pretreated with chloroquine (CQ; $10 \mu \mathrm{M}, 30 \mathrm{~min}$ ), methylamine (MA; $5 \mathrm{mM}, 30 \mathrm{~min}$; Sigma Chemical Co.), swainsonine (SW; $5.8 \mu \mathrm{M}, 2 \mathrm{~h}$; Sigma Chemical Co.), or vehicle. Without changing medium, Hex B $(50 \mathrm{nM})$ or vehicle was then added to cells. $\left[{ }^{3} \mathrm{H}\right]$ Thymidine addition and cell harvesting were done as above.

Statistical evaluation. Data were subjected to ANOVA followed by Student-Newman-Keul test. A $P$ value $<0.05$ was considered to represent a significant difference between the two samples.

Radiolabeling and binding assays. ManBSA (molar ratio Man/BSA $=26: 1$; E.Y. Laboratories, Inc., San Mateo, CA) was radiolabeled with $\mathrm{Na}^{125} \mathrm{I}$ by the Chloramine $\mathrm{T}$ method as described by Greenwood et al. (24) to a specific activity of $2-6 \times 10^{6} \mathrm{cpm} / \mu \mathrm{g}$.

Adherent cells on microtiter well plates $\left(1 \times 10^{5}\right.$ cells/well $)$ were washed twice with $\mathrm{Ca}^{2+}$ - and $\mathrm{Mg}^{2+}$-free HBSS and were incubated at $4^{\circ} \mathrm{C}$ (on ice) in M199 containing ligand (total volume, $100 \mu \mathrm{l}$ ). Nonspecific binding was estimated by adding yeast mannan, $1.25 \mathrm{mg} / \mathrm{ml}$ (10). At the end of the incubation period, the reaction was stopped by washing cells three times with ice-cold HBSS and adding $100 \mu \mathrm{l}$ of $0.5 \mathrm{~N} \mathrm{NaOH}$. Assays were run in triplicate and radioactivity was quantitated by gamma-counter.

Specific binding was calculated by subtracting the nonspecific binding from the total binding. The maximum number of binding sites $\left(B_{\max }\right)$ and the dissociation constant $\left(K_{\mathrm{d}}\right)$ were estimated by Scatchard analysis (25).

Electron microscopy. To assess MR-ligand internalization, cells were grown to confluence on 16-mm diameter Nuclepore polycarbonate membrane (Costar Corp., Cambridge, MA), and treated with colloidal gold-ManBSA (concentration: $50 \mathrm{nM}$; particle size of gold, $10 \mathrm{~nm}$; E.Y. Laboratories, Inc.) at $37^{\circ} \mathrm{C}$ for $30 \mathrm{~min}$ in $\mathrm{CO}_{2}$ incubator, then washed twice with HBSS and fixed with $2.5 \%$ glutaraldehyde in $0.1 \mathrm{M}$ cacodylate buffer, $\mathrm{pH}$ 7.4. Thin vertical sections of paraffin-embedded cells were subjected to transmission electron microscopy.

Indirect immunofluorescence. For immunolocalization of the bovine ASM putative MR, confluent cells in a four-well chamber slide (Nunc, Inc., Naperville, IL) were fixed with cold $100 \%$ methanol (kept in freezer set to $-20^{\circ} \mathrm{C}$ ) for $12 \mathrm{~min}$. Cells were then incubated with primary antibody (goat antiserum developed against purified human MøMR or preimmune goat serum, diluted 1:50 in PBS containing 3\% BSA for 60 min at room temperature. After incubation with primary antibody, cells were washed with PBS three times. Nonspecific binding of secondary antibody was blocked by incubation with $10 \%$ (vol/vol) preimmune rabbit serum for $1 \mathrm{~h}$. The cells were then incubated with FITC-conjugated rabbit serum against goat IgG (1:64 dilution, Sigma Chemical Co.) for $45 \mathrm{~min}$ at room temperature in the dark, washed three times with PBS containing methyl green $(0.2 \mathrm{mg} / \mathrm{ml}$, Sigma Chemical Co. $)$ for quenching of nonspecific fluorescence, and examined by epifluorescence microscopy.

Purification of putative ASM-MR. The putative MR from cultured ASM cells was isolated by affinity chromatography on mannose-Sepharose according to Lennartz et al. (26). Approximately $10^{8}$ ASM cells were homogenized using a hand-held Polytron homogenizer (Brinkmann Instruments, Inc., Westbury, NY) in $20 \mathrm{ml}$ of eluting buffer $(10 \mathrm{mM}$ Tris-HCl, pH $6.0 ; 1.25 \mathrm{M} \mathrm{NaCl} ; 15 \mathrm{mM}$ EDTA) containing $1 \mathrm{mM}$ PMSF at $4^{\circ} \mathrm{C}$. Homogenates were subjected to washing, treated with Triton X-100 (1\% vol/vol), loaded onto the affinity column, and eluted with alpha-methylmannoside $(0.2 \mathrm{M})$, as previously described (26). The partially purified mannose receptor $(2 \mu \mathrm{g})$ was subjected to electrophore- sis in $7.5 \%$ polyacrylamide gel in SDS under reducing conditions (27). Proteins were stained using the Silver Stain Plus kit (Bio-Rad Laboratories, Inc., Hercules, CA).

Immunoprecipitation of MR from bovine ASM cells. Approximately $6 \times 10^{6}$ cells were detached in cell lysis cocktail, consisting of $5 \%$ (vol/ vol) Triton $\mathrm{X}-100,2.5 \%$ (wt/vol) sodium deoxycholate, and $100 \mathrm{mM}$ EDTA, in $10 \mathrm{mM}$ PBS, pH 7.2. The lysed cells were centrifuged and the supernatant was diluted with $100 \mu \mathrm{l}$ of cell lysis cocktail and $10 \mu \mathrm{l}$ of concentrated PMSF. The sample was precleared by incubating with $200 \mu \mathrm{l}$ of recombinant protein G-Sepharose 4B conjugate (Zymed Laboratories, Inc., South San Francisco, CA) for $30 \mathrm{~min}$ at room temperature. The supernatant was collected after centrifugation, and goat antiMøMR immune serum or preimmune serum was added for overnight incubation at $4^{\circ} \mathrm{C}$. The pellet was washed six times with a solution consisting of $1.0 \%$ (vol/vol) Triton X-100, $0.5 \%$ (wt/vol) sodium deoxycholate, and $1.0 \%$ SDS, dissolved in $10 \mathrm{mM}$ PBS, pH 7.2. The pellet was suspended in $15 \mu \mathrm{l}$ of Laemmli sample buffer (27), frozen, and thawed. Immune complexes were dissociated by immersing the tube in a boiling water bath for $5 \mathrm{~min}$, followed by centrifugation. The supernatant was analyzed by SDS-PAGE in mini-gel system under reducing condition.

Metabolic labeling and immunoprecipitation. Confluent cells (two T-75 flasks) were incubated in starvation media (Cys ${ }^{-} / \mathrm{Met}^{-} \mathrm{RPMI}$; Tissue Culture Support Center, Washington University, School of Medicine, containing $10 \%$ dialyzed FCS) for $30 \mathrm{~min}$, pulsed in fresh medium supplemented with $200 \mu \mathrm{Ci} / \mathrm{ml}$ trans $-\left[{ }^{35} \mathrm{~S}\right.$-]methionine (Amersham Corp.) for $4 \mathrm{~h}$, and chased for $1.5 \mathrm{~h}$ in excess cold methionine as described previously (28). Cells were washed with PBS and lysed with $0.5 \%$ Triton X-100. Cell lysates were precleared with protein A-Sepharose $4 \mathrm{~B}$ conjugate/rabbit anti-mouse IgG (intermediate bridging antibody; Sigma Chemical Co.) complexes before adding $\mathrm{mAb}_{15}(1 \mu \mathrm{g} / \mathrm{ml})$ and incubating at $4^{\circ} \mathrm{C}$ overnight. The receptor/antibody complexes were precipitated with rabbit anti-mouse IgG/protein A-Sepharose beads and subjected to SDS-PAGE and autoradiography.

Enzyme preparations. Purified human placental Hex B was prepared by a modification (29) of the method of Geiger and Arnon (30) as described previously (7). Hex B is homogenous by electrophoresis on cellulose acetate gel (31) and on PAGE in denaturing (27) and nondenaturing conditions.

Preparation of human macrophage mannose receptor antibody. MøMR was isolated from human placenta by affinity chromatography on mannose-Sepharose as previously described (20). A goat antiserum against purified human MøMR was obtained as described by Stephenson and Shepard (32).

Monoclonal antibody directed against human MøMR $\left(\mathrm{mAb}_{15}\right)$ was developed according to Harlow and Lane (33). Balb/c mice were immunized with purified human placenta MøMR (50 $\mu \mathrm{g}$ in complete Freund's adjuvant the first time, followed by three boosters without adjuvant). Hybridoma cell lines producing antibodies against MøMR were selected in an enzyme-linked immunosorbent assay. A monoclonal antibody $\left(\mathrm{mA} \mathrm{b}_{15}\right)$ was affinity purified from culture supernatants and was classified by mouse monoclonal sub-isotyping kit (Hyclone Laboratories, Logan, UT) as $\mathrm{IgG}_{1}$ antibody. Binding experiments with $\mathrm{mAb}$ to human macrophages indicated that $m A b_{15}$ recognized the extracellular domain of MøMR (the monoclonal antibody $\mathrm{mAb} \mathrm{b}_{15}$ was found to be monospecific by a variety of methods including Western blot of human macrophage membrane proteins and immunoprecipitation of the MR from metabolically labeled human macrophages; S. E. Pontow, V. Kery, and P. D. Stahl, manuscript in preparation). Each of these procedures resulted in the observation of a single specific band with an apparent molecular mass of about $175 \mathrm{kD}$.

\section{Results and Discussion}

Binding of ${ }^{125}$ I-ManBSA to bovine ASM cells. Mannose receptors have been isolated from various sources (10-18), but not from myocytes to date. Our previous findings that Hex-induced ASM 


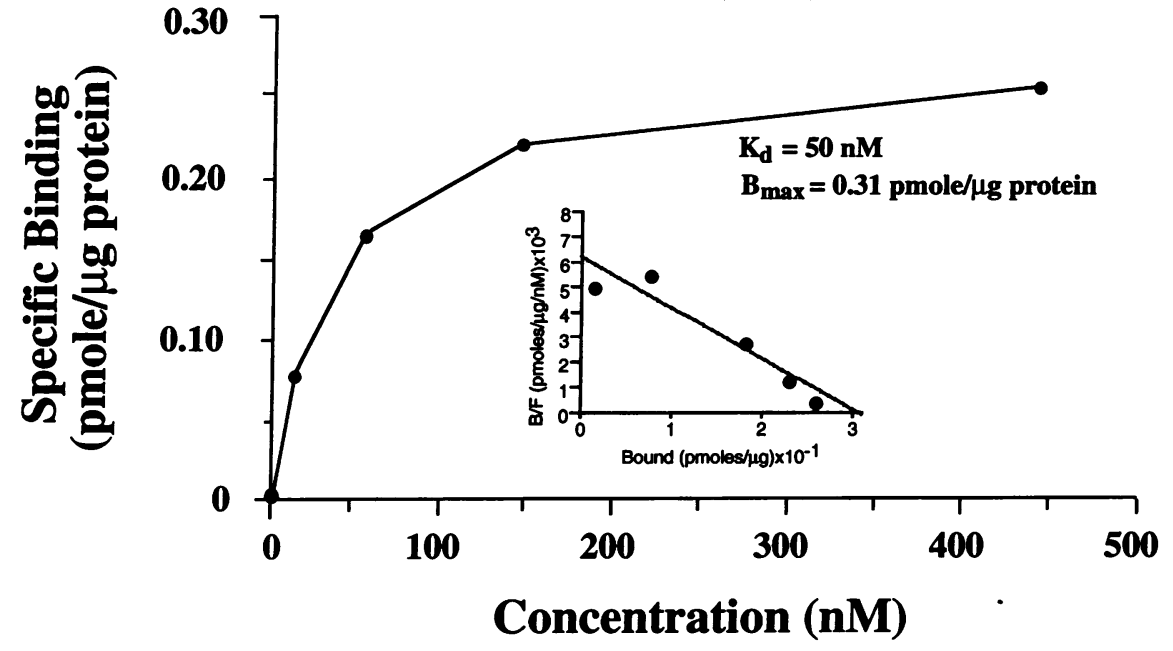

Figure 1. Concentration-dependent ${ }^{125} \mathrm{I}-\mathrm{Man}-$ BSA binding to bovine ASM cells. Adherent bovine ASM cells $\left(1 \times 10^{5}\right.$ cells/microtiter well) were washed twice and incubated at $4^{\circ} \mathrm{C}$ (on ice) for $90 \mathrm{~min}$ in M199 and ligand. Nonspecific binding was estimated by adding yeast mannan $(1.25 \mathrm{mg} / \mathrm{ml})$. Assays were run in triplicates. mitogenesis was inhibited by mannan (7) and that ManGP stimulated DNA synthesis in ASM cells (7) suggested that ASM cells express an MR. To assess whether the mannose-binding moiety possessed the essential receptor properties of specificity and saturability, adherent cells $\left(1 \times 10^{5}\right.$ cells/microtiter well $)$ were incubated in $0.1 \mathrm{ml}$ of M199 containing ${ }^{125} \mathrm{I}$-ManBSA $(140 \mathrm{nM})$ at $4^{\circ} \mathrm{C}$ (on ice) for various time periods, up to 90 min. Binding of ligand to cells was specific as it was inhibited by mannan (average inhibition: 72\%). Maximal binding occurred at $60 \mathrm{~min}$ and was maintained at $90 \mathrm{~min}$ time point (data not shown). Specific binding was saturable with increasing concentrations of ligand in the incubation mixture (Fig. 1). Scatchard analysis of data showed a maximum number of binding sites $\left(B_{\max }\right)$ of $0.31 \mathrm{pmol} / \mu \mathrm{g}$ protein and a $K_{\mathrm{d}}$ value of $50 \mathrm{nM}$. Scatchard transformation of the data was linear, suggesting a single population of receptors (Fig. 1, inset). Thus, the ASM mannose binding moiety shows the properties of specificity and saturability of a true receptor.

Internalization of colloidal gold-ManBSA by ASM cells. Upon ligand binding, receptors involved in endocytosis such as the MøMR, are localized in clathrin-coated pits on the plasma membrane (34); to assess whether this was the case for the ASM-MR, we used electron microscopy in ASM cells. Sections of cells treated with colloidal gold-ManBSA for $30 \mathrm{~min}$ at $37^{\circ} \mathrm{C}$ showed gold particles associated with clathrin-coated pits (Fig. 2). There were also multiple gold particles associated with large cytoplasmic vesicles identifiable as endosomes (Fig. 3), indicating endocytic internalization of receptor-ligand complexes. Receptor-mediated endocytosis is inhibited by weak bases (CQ, MA) and mannosyl-specific endocytosis is inhibited by the mannosidase II inhibitor, $\mathrm{SW}$, that prevents the recycling of ligand-free receptors to the plasma membrane (12). Electron microscopic examination of ASM cells pretreated with SW (5.8 $\mu \mathrm{M}, 2 \mathrm{~h}$ ) (35), CQ (10 $\mu \mathrm{M}, 30 \mathrm{~min})(36)$, or MA (5 mM, 30 min) (36) showed a clear reduction of colloidal gold particles in both the clathrin-coated pits and endosomal vesicles (data not shown), providing additional evidence of endosomally directed internalization of the MR.

Effect of weak bases and SW on Hex B-induced mitogenesis. To obtain additional evidence that the putative MR involved in ASM cell mitogenesis is internalized to the endosomal compartment, we tested the effect of SW, CQ, and MA on Hexinduced $\left[{ }^{3} \mathrm{H}\right]$ thymidine incorporation. Pretreatment of cells with
SW caused $50 \%$ inhibition of the Hex B (50 nM)-induced increase in $\left[{ }^{3} \mathrm{H}\right]$ thymidine incorporation: $330 \pm 43 \%$ above vehicle-treated control for Hex $B$ alone versus $165 \pm 6 \%$ above vehicle-treated control for SW + Hex B ( $n=4, P<0.05$, Fig. 4). Pretreatment of cells with CQ or MA completely blocked Hex B-induced increase in $\left[{ }^{3} \mathrm{H}\right]$ thymidine incorporation $(n=4, P$ $<0.05$, Fig. 4). Cells treated with CQ or MA were $>99 \%$ viable as determined by trypan blue exclusion.

Taken together, the electron microscopy observations on ligand binding and internalization, the inhibition by CQ, MA, and SW, and the inhibitory effect of these agents on Hex Binduced mitogenesis support the contention that the mitogenic effect is mediated by a mannosyl-specific receptor that mediates endosomally directed internalization. The involvement of endosomes is indicated by the effect of CQ and MA, agents that act by raising the $\mathrm{pH}$ of these vesicles and preventing the low $\mathrm{pH}-$ induced uncoupling of ligands and receptors (12). Mannosyl specificity is indicated by the effect of SW that, by inhibiting the activity of mannosidase II, results in mannose receptors saturated with endogenous mannosyl ligands (35). A corollary of these observations is that at least a portion of the MR present on the cell surface recycles to the plasma membrane from the endosome after internalization. Although the inhibitory effect of $\mathrm{CQ}, \mathrm{MA}$, and $\mathrm{SW}$ on $\left[{ }^{3} \mathrm{H}\right]$ thymidine incorporation indicates that the trophic effect of the ligand-receptor complex is accompanied by internalization, we cannot conclude that internalization is needed for the trophic effect to occur, since these agents prevent ligand binding not internalization per se (12). Finally, it may be surprising that yeast mannan, which presumably blocks ligand binding competitively, does not stimulate mitogenesis (7). However, this mixture of highly branched, complex molecules may well inhibit ligand binding by steric hindrance without having the right configuration for an appropriate productive binding to the ASM-MR.

Characterization and immunolocalization of bovine ASM mannose receptor. The functional and topographic similarity of the ASM cell putative MR with the MøMR prompted an initial assessment of its biophysical characteristics. The putative MR was purified by mannose affinity chromatography. By SDSPAGE, the apparent molecular mass of the major form of mannose-sepharose affinity purified bovine ASM-MR was $\sim 175$ $\mathrm{kD}$ coincident with that of MøMR (Fig. 5). The microheterogeneity of the three forms of ASM-MR may be due to processing or a difference in carbohydrate content. 


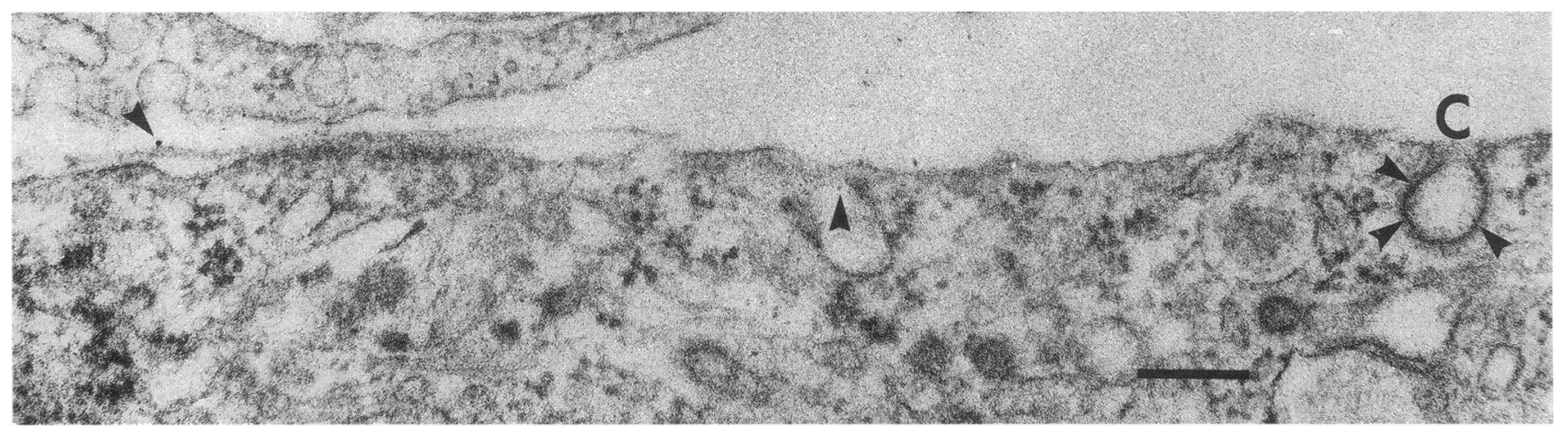

Figure 2. Endocytosis of colloidal gold-ManBSA via clathrin-coated pits in bovine ASM cells. Cells were grown to confluence on Nuclepore polycarbonate membrane and were treated with colloidal gold-ManBSA (particle size, $10 \mathrm{~nm}$; ManBSA concentration, $50 \mathrm{nM}$ ) at $37^{\circ} \mathrm{C}$ for 30 min in a $\mathrm{CO}_{2}$ incubator. Cells were washed twice with HBSS and fixed with glutaraldehyde. Final magnification: $\times 71,020$. C, Clathrin-coated pit. Arrowhead indicates gold particle. Bar, $195 \mathrm{~nm}$.

The $M_{\mathrm{r}}$ coincidence, in turn, prompted an assessment of a possible immunologic cross-reactivity between the two receptors. In fact, bovine ASM-MR was immunoprecipitated by a goat anti-human MøMR serum (Fig. 6 A, lane 2) and a monoclonal antibody $\left(\mathrm{mAb}_{15}\right)$ directed to human MøMR (Fig. $6 \mathrm{~B}$ ), indicating that the two receptors are immunologically related. The receptor protein appears as a single band in these experiments, as opposed to multiple bands in Fig. 5. Most likely, this is due to the difference in the protein quantities used for the gel electrophoresis assays. The immunologic cross-reactivity between ASM-MR and MøMR allowed the use of anti-human MøMR antibodies to assess the subcellular localization of the ASM-MR by immunofluorescence microscopy.

Indirect immunofluorescent staining of bovine ASM cells using goat antiserum against purified human MøMR showed a punctate cytoplasmic signal consistent with endosomal localization (Fig. $7 \mathrm{~B}$ ), in contrast to the diffuse nonspecific staining of nuclei and cytoplasm in control cells (Fig. $7 \mathrm{~A}$ ).

The specificity of cross-reactivity was tested by determining the effect of the antiserum on ${ }^{125} \mathrm{I}-\mathrm{ManBSA}$ binding. Preincubation of ASM cells with goat anti-human MøMR antiserum (30 min at $\left.4^{\circ} \mathrm{C}\right)$ inhibited binding of ${ }^{125} \mathrm{I}-\mathrm{ManBSA}(1 \mu \mathrm{g} / 100 \mu \mathrm{l} /$ $10^{5}$ cells) in a concentration-dependent manner (Table I). The maximal inhibition occurred with 1:50 dilution of anti-human MøMR serum and the degree of inhibition was comparable with that obtained with mannan ( 78 vs. $72 \%$, respectively). Thus, the functional characteristics and subcellular location of the putative MR in ASM cells are similar to those of the MøMR (12) and the homology is strengthened by the biochemical and immunologic data. The protein isolated from the bovine ASM cells by mannose affinity chromatography has an $M_{\mathrm{r}}$ coincident with that of the MøMR (Fig. 5), and a protein with the same $M_{\mathrm{r}}$ is immunoprecipitable from ASM cell extracts by polyclonal and $\mathrm{mAb}_{15}$ against the MøMR (Fig. 6, $A$ and $B$ ). Furthermore, immunofluorescence microscopy indicates that this cross-reacting protein has a subcellular distribution consistent with endosomal distribution (Fig. 7 B). By themselves, these data would only allow us to conclude that there exists in ASM cells a (possibly unrelated) protein that cross-reacts with an antiserum to, and has the same $M_{\mathrm{r}}$ and location as, the MøMR. However, the finding that the same antiserum also inhibits ${ }^{125} \mathrm{I}-\mathrm{ManBSA}$ binding to ASM cells strongly suggests that this protein is related to or homologous with the MøMR.
Effect of antibodies to MøMR on $\left[{ }^{3} \mathrm{H}\right]$ thymidine incorporation. The inhibition of ${ }^{125} \mathrm{I}-\mathrm{ManBSA}$ binding/uptake by the goat antiserum suggested the possibility that, upon binding to the putative MR, the antibodies may have an agonistic effect, as in the case of other receptor systems (37-41). In fact, exposure of ASM cells to goat anti-MøMR resulted in stimulation of $\left[{ }^{3} \mathrm{H}\right]$ thymidine incorporation (Fig. $8 \mathrm{~A}$ ); the maximal response occurred with 1:50 dilution of antiserum $(5,160 \pm 300 \%$ of goat preimmune serum control: control $=100 \%, n=4)$. Addition of excess amount of the polyclonal antibody to the cells attenuated the Hex B (50 nM)-stimulated increases in $\left[{ }^{3} \mathrm{H}\right]$ thymidine incorporation in a dose-dependent manner $(n=4$, Table II).

We also tested the effect of monoclonal antibody $\mathrm{mAb}_{15}$ on $\left[{ }^{3} \mathrm{H}\right]$ thymidine incorporation. Exposure to the antibody increased $\left[{ }^{3} \mathrm{H}\right]$ thymidine incorporation in ASM cells in a concentration-dependent manner and the maximal effect was comparable with that of Hex B; 876 $\pm 83 \%$ of control $\left(\mathrm{mAb}_{15}, 20 \mathrm{nM}\right)$ versus $809 \pm 83 \%$ of control $(\mathrm{Hex} B, 50 \mathrm{nM})$, control $=100 \%$, $n=4$ (Fig. $8 \mathrm{~B}$ ). The stimulatory effect of $\mathrm{mAb}_{15}$ on DNA synthesis was inhibited by mannan $(0.1-1.0 \mathrm{mg} / \mathrm{ml})$ very effectively (72-100\% inhibition). This agonistic effect of antibodies had its counterpart: an antagonistic effect was also observed upon preincubation of cells with excess amounts of $\mathrm{mAb}_{15}(50-$ $100 \mathrm{nM})$ that inhibited Hex $\mathrm{B}(50 \mathrm{nM})$-induced increase in $\left[{ }^{3} \mathrm{H}\right]$ thymidine incorporation in a dose-dependent manner (53$100 \%$ inhibition, Table III). At $100 \mathrm{nM}, \mathrm{mAb}_{15}$ inhibited the Hex response to below the basal value.

The findings that anti-human MøMR antiserum stimulates ASM mitogenesis even more effectively than Hex B and that the effect is mannan-inhibitable provide strong support both to the homology of the ASM receptor with the MøMR, and, most importantly, to the direct involvement of the ASM-MR in mitogenesis stimulation (Fig. $8 \mathrm{~A}$ ). This contention receives additional support from the observation that $m A b_{15}$, a monoclonal antibody to the extracellular domain of the MøMR, stimulates $\left[{ }^{3} \mathrm{H}\right]$ thymidine incorporation in ASM cells (Fig. $8 \mathrm{~B}$ ) as effectively as Hex B at comparable concentrations. The specificity of the agonistic effect is indicated by the antagonistic effect observed, i.e., inhibition of the Hex B-mediated mitogenic effect by pretreatment of cells with the same antibody (Tables II and III); this effect is similar to, but more effective than, that induced by high concentration of $\mathrm{Hex} \mathrm{B}$ or $\mathrm{mAb}_{15}$ alone (Fig. 8 B). 

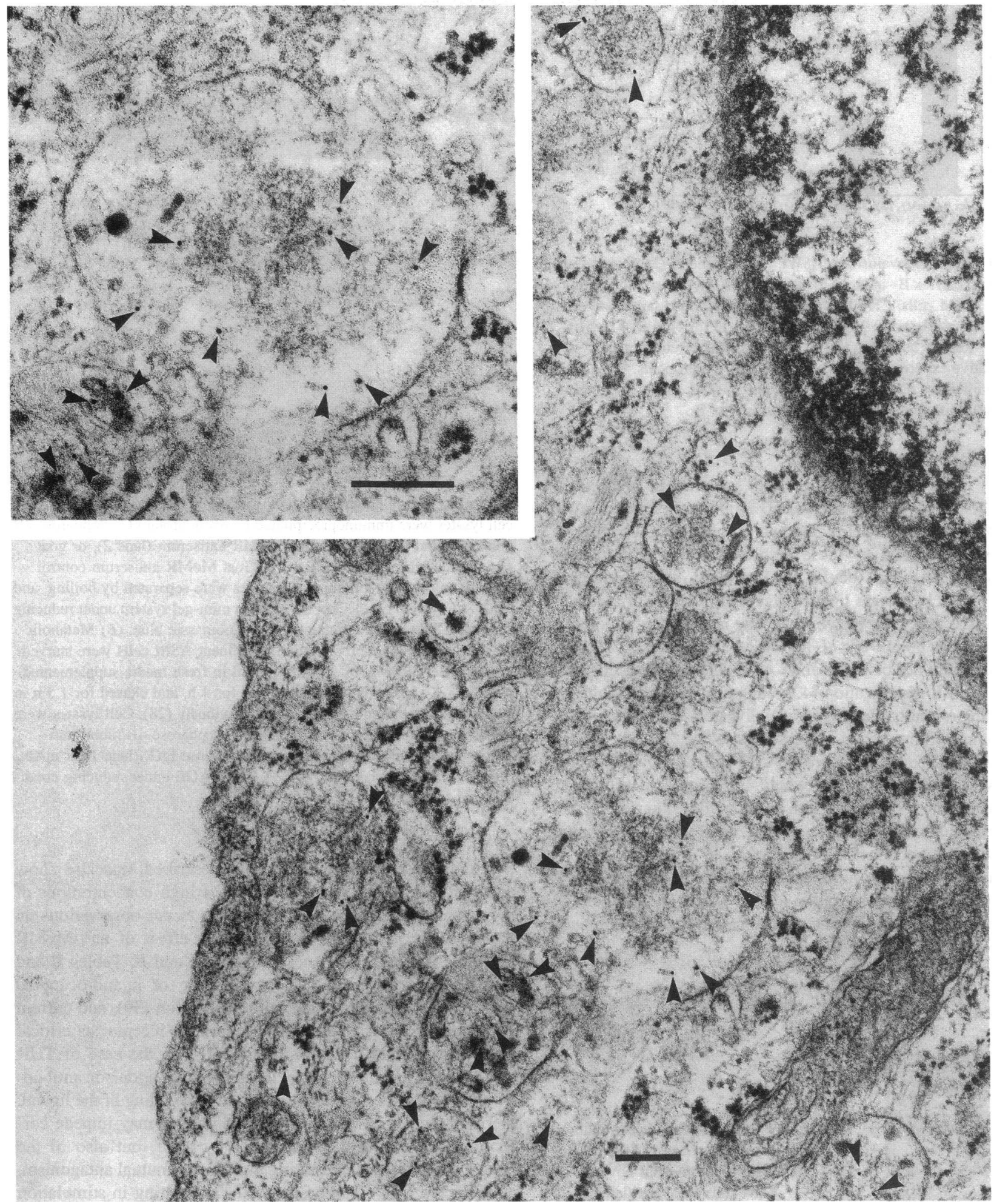

Figure 3. Electron microscopy of bovine ASM cells exposed to colloidal gold-ManBSA. Cells were grown to confluence on Nuclepore polycarbonate membrane and were treated with colloidal gold-ManBSA (particle size, $10 \mathrm{~nm}$; ManBSA concentration, $50 \mathrm{nM}$ ) at $37^{\circ} \mathrm{C}$ for $30 \mathrm{~min}$ in a $\mathrm{CO}_{2}$ incubator. Cells were washed twice with HBSS and fixed with glutaradehyde. Final magnification: $\times 55,640(\times 90,760$ for inset). Arrowhead indicates gold particle. Bar, $190 \mathrm{~nm}$.

Agonistic-antagonistic effects of antibody to receptors analogous to our findings have been described in the case of human growth hormone $(\mathrm{hGH})$ receptor $(37)$, indicating that ligand and antibodies to receptors can be agonists, self-antagonists, and mutual antagonists. Both hGH and mAb's to the hGH receptor are agonists at low concentration and self-antagonists 


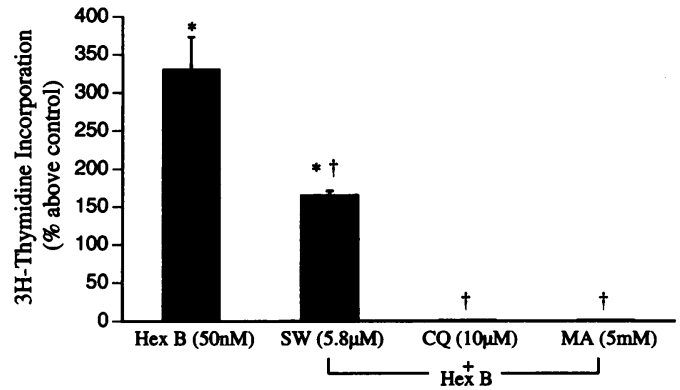

Figure 4. Effect of swainsonine (SW), chloroquine $(C Q)$, and methylamine $(M A)$ on Hex $\mathrm{B}$-induced increase in $\left[{ }^{3} \mathrm{H}\right]$-thymidine incorporation in bovine ASM cells. $\left[{ }^{3} \mathrm{H}\right]$-Thymidine incorporation assays were done as described in Methods. Vehicle control value for Hex B: 526 \pm 107 $\mathrm{cpm} /$ well. Results are mean \pm SEM of quadruplicate cultures from a representative experiment from a total of four experiments. ${ }^{*} P<0.05$, value significantly different from the control value. $\nmid P<0.05$, value significantly different from the response to Hex B.

at higher concentration. Furthermore, some mAbs are antagonists to hGH effects with a lower $50 \%$ inhibitory concentration in combination with hGH than when acting as self-antagonists. The model proposed by these authors favors ligand-induced sequential dimerization of the hGH receptor, and interference in this process by excess ligand, excess antibodies, or a combination of the two (37). However, if one accepts the hypothesis of a structural homology of the ASM-MR with the MøMR, this model may not be applicable. Available evidence does not support MøMR dimerization (42), suggesting instead multiplesite binding of multivalent ligands to diverse carbohydrate binding domains within a single receptor molecule $(12,43)$. In preliminary experiments, exposure of ASM cells to polyclonal goat antibody to MøMR, followed by anti-goat IgG, failed to show an enhancement of $\left[{ }^{3} \mathrm{H}\right]$ thymidine incorporation, suggesting that oligomerization is not a prerequisite for receptor activation (Lew, D. B., unpublished observations).

A model that seems more applicable to our observations is that of the thyrotropin receptor (THR) $(40,41)$. Monoclonal antibodies to the THR showing agonistic activity, both competi-

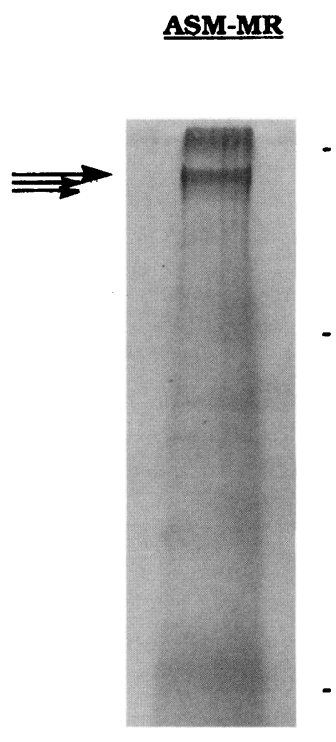

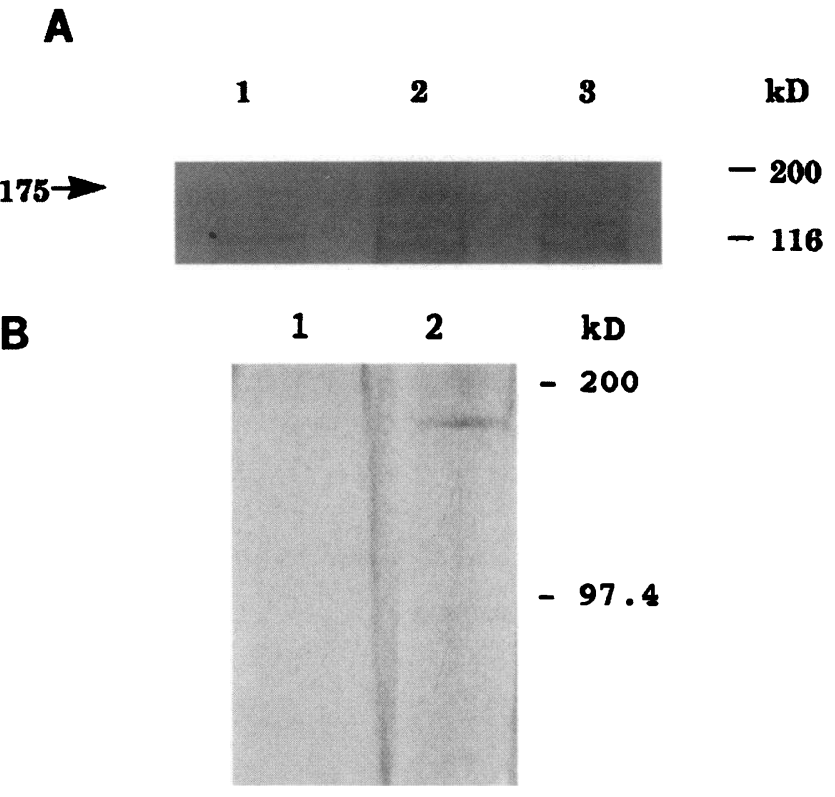

Figure 6. (A) Immunoprecipitation of ASM-MR from ASM cells. ASM cell lysates were immunoprecipitated by using protein $G$-Sepharose 4B conjugate and goat anti-human MøMR antiserum (lane 2), or goat preimmune serum (lane 1). Lane 3, Goat MøMR antiserum control without cell lysates. Immune complexes were separated by boiling, and analyzed by SDS gel electrophoresis in a mini-gel system under reducing condition. Proteins were stained with Coomassie blue. $(B)$ Metabolic labeling and immunoprecipitation. Confluent ASM cells were starved in $\mathrm{Cys}^{-} / \mathrm{Met}^{-}$RPMI for $30 \mathrm{~min}$, pulsed in fresh media supplemented with $200 \mu \mathrm{Ci} / \mathrm{ml}$ trans- $\left[{ }^{35} S\right]$ methionine for $4 \mathrm{~h}$, and chased for $1.5 \mathrm{~h}$ in excess cold methionine, as described previously (28). Cell lysates were immunoprecipitated by using protein A-Sepharose $4 \mathrm{~B} /$ rabbit antimouse IgG complexes and $\mathrm{mAb}$ control mouse $\mathrm{IgG}_{1}$ (lane 1) or $\mathrm{mAb}_{15}$ (lane 2). Proteins were subjected to SDS-PAGE under reducing condition and autoradiography.

tive and noncompetitive, have been described, that also show antagonistic activity in the presence of high concentrations of thyrotropin (38). These data are similar to our observations on the agonistic and additive antagonistic effect of anti-MøMR antibodies on cell mitogenesis (Fig. 8, $A$ and $B$; Tables II and III). Experiments involving cross-linking of ligand-occupied THR do not suggest receptor oligomerization (39), and current views favor conformational changes of the receptor as critical inducers of signal transmission $(40,41)$. In the case of THR $(40,41)$, the binding site(s) for the stimulating agonistic antibodies are in the same domain involved in the binding of the ligand. Steric hindrance by excess bound antibodies may impede correct binding not only of the antibody itself, but also of the ligand, and vice versa, resulting in self- and mutual antagonism, respectively. The common mechanism resulting in stimulation is a conformational deformation of the receptor, but this may originate from distinct and potentially mutually interfering sites, at which different moieties bind.

Conclusions. Previous work on stimulation of mannan-inhibitable mitogenesis in ASM cells upon exposure to mannosylrich glycoproteins suggested the involvement of a moiety recognizing mannosyl residues (7). The present work was aimed at assessing $(a)$ whether the properties of this moiety are consistent with those of a receptor; $(b)$ whether the putative receptor is internalized to the endosomal compartment; $(c)$ whether the 

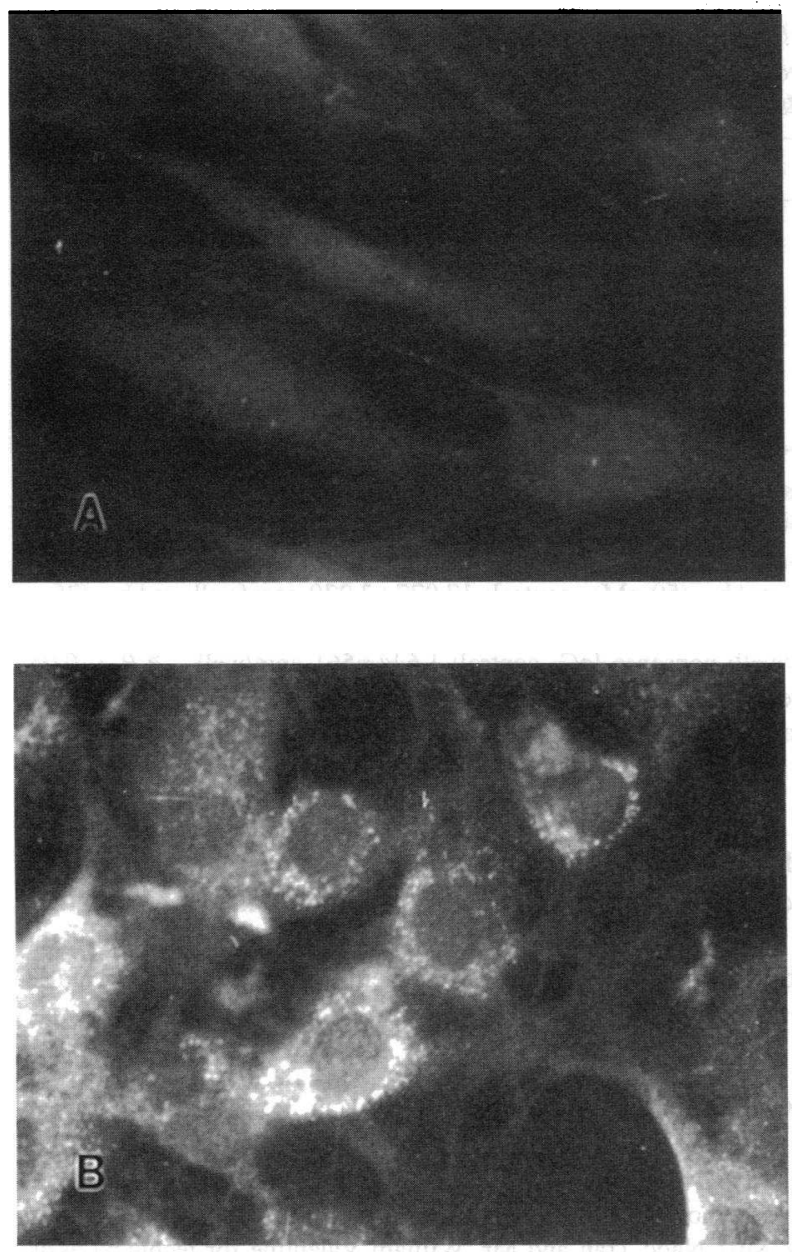

Figure 7. Immunolocalization of putative bovine ASM-MR. Confluent cells in a four-well chamber slide were fixed with cold $100 \%$ methanol. Fixed cells were incubated with either preimmune goat serum $(A)$ or goat antiserum against human purified MøMR $(B)$. FITC-conjugated rabbit serum against goat IgG was used as secondary antibody. Note the punctate cytoplasmic signal in anti-MøMR antiserum-treated cells as compared with the control cells. Final magnification: $\times 625$.

Table I. Inhibition of ${ }^{125}$ I-ManBSA Binding to Bovine ASM Cells by Goat Anti-Human MøMR

\begin{tabular}{cc}
$\begin{array}{c}\text { Goat anti-human MøMR } \\
\text { (dilution) }\end{array}$ & $\begin{array}{c}\text { 125I-ManBSA binding cpm } \pm \text { SEM } / 10^{5} \text { cells, } \\
\mathrm{n}=3\end{array}$ \\
\hline- & $15,759 \pm 4,758$ \\
$1: 500$ & $8,849 \pm 2,709^{*}$ \\
$1: 100$ & $6,079 \pm 681^{*}$ \\
$1: 50$ & $3,523 \pm 768^{*}$ \\
$1: 38$ & $3,790 \pm 1,430^{*}$
\end{tabular}

Cells were pretreated with goat anti-human mannose receptor for 30 min before the addition of ${ }^{125} \mathrm{I}-\mathrm{ManBSA}\left(1 \mu \mathrm{g} / 10^{5}\right.$ cells). Incubations were continued for $90 \mathrm{~min}$ at $4^{\circ} \mathrm{C}$. $* P<0.05$ : value significantly different from ${ }^{125} \mathrm{I}$-ManBSA alone. Results are from a representative experiment from a total of three experiments.
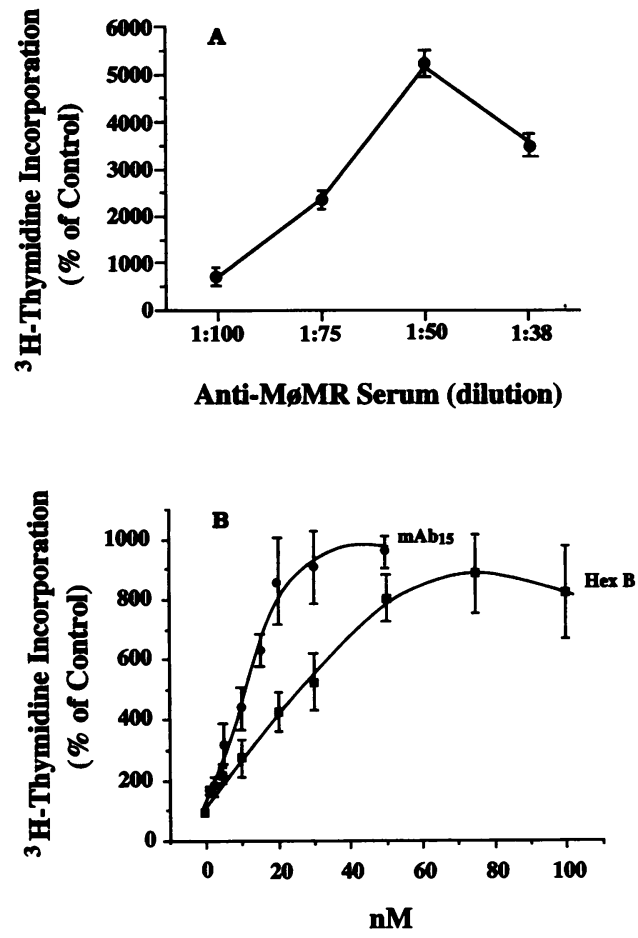

Figure 8. Effect of anti-MøMR serum, $\mathrm{mAb}{ }_{15}$ on $\left[{ }^{3} \mathrm{H}\right]$ thymidine incorporation in bovine ASM cells. Quiescent cells were exposed to $(A)$ antiMøMR serum or nonimmune serum (1:100 to $1: 38$ dilution); $(B) \mathrm{mAb}_{15}$ (0-50 nM: •-๑), control for $\mathrm{mAb}_{15}$ (mouse $\mathrm{IgG}_{1}$ raised against irrelevant antigen), Hex B (0-100 nM: - - , or vehicle for Hex B. $\left[{ }^{3} \mathrm{H}\right]-$

Thymidine incorporation assays were done according to Methods. Nonimmune serum control, $2710 \pm 316 \mathrm{cpm} /$ well $=100 \%$; nonsense $\mathrm{IgG}_{1}$ control, $1292 \pm 72 \mathrm{cpm} /$ well $=100 \%$; vehicle control for Hex B, $1178 \pm 186 \mathrm{cpm} /$ well $=100 \%$. Results are mean \pm SEM of quadruplicate cultures from a representative experiment from a total of four experiments.

receptor bears any structural relationship to the MøMR; and (d) whether the receptor is directly responsible for the observed mitogenic effect. We have obtained answers to these questions.

The data from the ${ }^{125} \mathrm{I}$-ManBSA binding experiments indicate specificity and saturability of binding, arguing for a binding site. The electron microscopy data indicate the association of the ligand-occupied receptor with clathrin-coated pits and its subsequent internalization in endosomes.

Internalization of the ASM-MR to the endosome is further indicated by inhibition of ligand uptake upon exposure of cells to the weak bases CQ and MA, and to SW. This is also indicated by the inhibition of Hex $\mathrm{B}$-stimulated $\left[{ }^{3} \mathrm{H}\right]$ thymidine incorporation by these agents. In addition, our data on SW inhibition indicate that the internalized receptor stimulating $\left[{ }^{3} \mathrm{H}\right]$ thymidine incorporation has mannosyl specificity. However, one may not conclude that internalization is needed for the trophic effect to occur, since CQ, MA, and SW prevent binding. Signal transduction has been shown to be independent of receptor-ligand endocytosis in several instances (44-46) and dependent on endocytosis in some (47), but our data do not allow us to discriminate between the two possibilities.

Functional characteristics, subcellular location, and apparent molecular size suggest a degree of homology between the ASMMR and the MøMR. A structural homology is indicated by the immunologic cross-reactivity. 
Finally, the competitive, agonistic, and antagonistic effects of the antibodies to the MøMR cross-reacting with the ASMMR allow us to conclude with confidence that this mannosylspecific receptor is indeed responsible for the mitogenic effect in ASM cells.

Further studies are needed to clarify the structural basis of the signal resulting from the binding of mannosyl-rich ligands to the ASM-MR. It is possible that the ASM-MR/ligand interaction triggers a signal that results in the synthesis of endogenous mitogenic factors. However, in preliminary experiments (Lew, D. B., unpublished observations), conditioned medium from Hex-stimulated ASM cells failed to exert a mitogenic effect on naive ASM cells. Thus the possibility of an indirect effect due to the generation of endogenous mitogenic factors seems unlikely.

In addition to signal generation, of interest is also the mechanism of signal transduction from the receptor to the cytoplasmic machinery that controls endocytosis and cell division. GTPbinding proteins (G-proteins) play a role in endocytic processes $(48,49)$ and in the cytoplasmic transduction of the receptor signal (50). Preliminary findings by our group (51) suggest that the bovine ASM-MR is coupled to phospholipase $\mathrm{A}_{2}\left(\mathrm{PLA}_{2}\right)$ via a pertussis toxin-sensitive G-protein; it is not known, however, if the G-protein is also involved in the endocytic or mitogenic process. Additional recent observations indicate that an early, transient surge of cAMP (52) and activation of protein kinase C (53) are also associated with Hex-induced mitogenesis in ASM cells, but their mutual relationships are likewise unclear at this time.

In conclusion, our data indicate that the MR identified in this work undergoes endocytosis and shares structural, topological, and functional properties with the MøMR, while it also stimulates mitogenesis. The ASM cells are not phagocytic and the main function of MR in ASM cells seems to be mitogenic; whereas a trophic or mitogenic function of the MøMR has not been observed so far. Interestingly, after submission of this manuscript, Lambeau et al. (54) and Ishizaki et al. (55) reported cloning and expression of a membrane receptor for secretory $\mathrm{PLA}_{2}$ from rabbit skeletal muscle and bovine corpora lutea, respectively, that show a remarkable structural homology with

Table II. Inhibition by High Concentrations of MøMR Antiserum of the Effect of Hex $B$ on $\left[{ }^{3} H\right.$ ]Thymidine Incorporation in Bovine ASM Cells

\begin{tabular}{cc}
\hline Goat anti-Human MøMR (dilution) & {$\left[{ }^{3} \mathrm{H}\right]$ Thymidine incorporation } \\
\hline & $\%$ of Hex $B$ response \pm SEM, $n=4$ \\
- & 100 \\
$1: 50$ & $43 \pm 3^{*}$ \\
$1: 38$ & $18 \pm 2^{*}$ \\
$1: 25$ & $2 \pm 1^{*}$
\end{tabular}

Cells were pretreated with goat anti-human MøMR for $30 \mathrm{~min}$ before the addition of Hex B $(50 \mathrm{nM})$ or vehicle at $37^{\circ} \mathrm{C} .\left[^{3} \mathrm{H}\right]$ Thymidine incorporation assays were done according to the protocol. Vehicle control for Hex B: $822 \pm 97 \mathrm{cpm} /$ well; Hex B $(50 \mathrm{nM}): 5,163 \pm 303 \mathrm{cpm} /$ well; nonimmune goat serum control: $1,958 \pm 265 \mathrm{cpm} /$ well; goat antihuman MøMR serum: 101,092 $\pm 5,932$ (1:50), 68,530 $\pm 3,172$ (1:38), $56,233 \pm 2,112(1: 25) \mathrm{cpm} /$ well. $\quad * P<0.05$, value significantly different from Hex $B$ alone. Results are from a representative experiment from a total of three experiments.
Table III. Inhibition by High Concentrations of $m A b_{15}$ of the Effect of Hex B on $\left[{ }^{3} \mathrm{H}\right]$ Thymidine Incorporation in Bovine ASM Cells

\begin{tabular}{cc}
\hline $\mathrm{mAb}_{15}$ & ${ }^{3} \mathrm{H}$-Thymidine incorporation \\
\hline$n M$ & $\%$ of Hex B response \pm SEM, $n=4$ \\
- & 100 \\
50 & $47 \pm 10^{*}$ \\
75 & $1 \pm 5^{*}$ \\
100 & $<0^{*}$ \\
\hline
\end{tabular}

Cells were pretreated with $\mathrm{mAb} \mathrm{b}_{15}$ for 30 min before the addition of $\mathrm{Hex}$ B $(50 \mathrm{nM})$ or vehicle. $\left[{ }^{3} \mathrm{H}\right]$ Thymidine incorporation assays were done according to the protocol. Hex B $(50 \mathrm{nM})$-vehicle: $11,375 \pm 1,538 \mathrm{cpm} /$ well; $\mathrm{mAb}_{15}$ (50 nM)-control: 17,977 $\pm 3,270 \mathrm{cpm} / \mathrm{well}$; $\mathrm{mAb}_{15}$ (75 $\mathrm{nM})$-control: $3,132 \pm 572 \mathrm{cpm} /$ well; $\mathrm{mAb}_{15}(100 \mathrm{nM})$-control: $754 \pm 93$ $\mathrm{cpm} /$ well; nonsense $\mathrm{IgG}_{1}$ control: $1,644 \pm 561 \mathrm{cpm} /$ well. $* P<0.05$, value significantly different from Hex $B$ alone. Results are from a representative experiment from a total of three experiments.

the human MøMR. Therefore, it will be interesting to compare the detailed structure of the ASM-MR with that of the MøMR, and that of the secretory PLA 2 receptors in order to understand the basis of what appear to be different main functions of related receptors in different cell types.

\section{Acknowledgments}

This work is dedicated to the late Dr. Hoon Sang Lew, to whom the leading author is indebted for his support and inspiration. The authors thank Miss Ngoc Tran and Mr. William Valentine for technical assistance, Mrs. Ibby MacDonnell and Mrs. Lynn Hauser for manuscript preparation, and Dr. Russell W. Chesney and Dr. Henry G. Herrod for careful review of this manuscript.

This work was supported in part by research grants from the Crippled Children's Foundation, LeBonheur Children's Medical Center, the American Lung Association, and National Institutes of Health grants HL-47022 (D. B. Lew) and AI-20015 (P. D. Stahl).

\section{References}

1. Dunnill, M. S., G. R. Massarella, and J. A. Anderson. 1969. A comparison of the quantitative anatomy of the bronchi in normal subjects, in status asthmaticus, in chronic bronchitis, and in emphysema. Thorax. 24:176-179.

2. Heard, B. E., and S. Hossain. 1973. Hyperplasia of bronchial muscle in asthma. J. Pathol. 110:319-331.

3. Takizawa, T., and W. M. Thurlbeck. 1971. Muscle and mucous gland size in the major bronchi of patients with chronic bronchitis, asthma and asthmatic bronchitis. Am. Rev. Respir. Dis. 104:331-336.

4. Tonnel, A. B., M. Joseph, P. H. Gosset, E. Fourmer, and A. Capron. 1983. Stimulation of alveolar macrophages in asthmatic patients after local provocation test. Lancet. i:1406-1408.

5. Murray, J. J., A. B. Tonnel, A. R. Brash, L. J. Roberts, P. Gosset, R. Workman, A. Capron, and J. A. Oates. 1986. Release of prostaglandin D2 into human airways during acute antigen challenge. $N$. Engl. J. Med. 315:800-804.

6. Lew, D. B., V. Chodimella, and C. G. Murlas. 1990. Guinea pig $\mathrm{O}_{z}$-induced airway hyperreactivity is associated with increased $N$-acetyl- $\beta$-glucosaminidase (NAGA) activity in bronchoalveolar fluid. Lung. 168:273-283.

7. Lew, D. B., and M. C. Rattazzi. 1991. Mitogenic effect of lysosomal hydrolases on bovine tracheal myocytes in culture. J. Clin. Invest. 88:1969-1975.

8. Sung, S. J., R. S. Nelson, and S. C. Silverstein. 1978. Yeast mannan inhibit binding and phagocytosis of zymosan by mouse peritoneal macrophages. Proc. Natl. Acad. Sci. USA. 75:1399-1403.

9. Kornfeld, S. 1992. Structure and function of the mannose-6-phosphate/ insulin-like growth factor II receptors. Annu. Rev. Biochem. 61:307-330.

10. Stahl, P., P. H. Schlesinger, E. Sigardson, J. S. Rodman, and Y. C. Lee. 
1980. Receptor-mediated pinocytosis of mannose glycoconjugates by macrophages: characterization and evidence for receptor recycling. Cell. 19:207-215.

11. Stahl, P. D. 1990. The macrophage mannose receptor: current status. Am. J. Respir. Cell Mol. Biol. 2:317-318.

12. Pontow, S. E., V. Kéry, and P. D. Stahl. 1992. Mannose receptor. Int. Rev. Cytol. 137:221-244.

13. Shepherd, V. L., and J. R. Hoidal. 1990. Clearance of neutrophil-derived myeloperoxidase by the macrophage mannose receptor. Am. J. Respir. Cell Mol. Biol. 2:335-340.

14. Otter, M., J. Kuiper, R. Bos, D. C. Rijken, and T. J. van Berkel. 1992. Characterization of the interaction both in vitro and in vivo of tissue-type plasminogen activator (t-PA) with rat liver cells. Effects of monoclonal antibodies to tPA. Biochem. J. 284:545-550.

15. Summerfield, J. A., J. Vergalla, and E. A. Jones. 1982. Modulation of a glycoprotein recognition system on rat hepatic endothelial cells by glucose and diabetes mellitus. J. Clin. Invest. 69:1337-1347.

16. Hattiwanger, R. S., and R. L. Hill. 1986. The ligand binding specificity and tissue localization of a rat alveolar macrophage lectin. J. Biol. Chem. 216:15696-15702.

17. Hattiwanger, R. S., and R. L. Hill. 1986. The isolation of a rat aveolar macrophage lectin. J. Biol. Chem. 261:7440-7444.

18. Gordon, S., and T. Makena. 1989. Receptors for mannosyl structures on mononuclear phagocytes. In Mononuclear Phagocytes. M. Zembala and G. L. Asherson, editors. Academic Press Inc., San Diego. 141-150.

19. Shepherd, V. L., B. I. Tarnowski, and B. J. McLaughlin. 1991. Isolation and characterization of a mannose receptor from human pigment epithelium. Invest. Opthalmol. \& Visual Sci. 32:1779-1784.

20. Lennartz, M. R., F. S. Cole, V. L. Shepherd, T. E. Wileman, and P. D. Stahl. 1987. Isolation and characterization of a mannose-specific endocytosis receptor from human placenta. J. Biol. Chem. 262:9942-9944.

21. Reise Sousa, C., P. D. Stahl, and J. M. Austyn. 1993. Phagocytosis of antigens by Langerhans cells in vitro. J. Exp. Med. 178:509-519.

22. Kotlikoff, M. I., R. K. Murray, and E. E. Reynolds. 1987. Histamineinduced calcium release and phorbol antagonism in cultured airway smooth muscle cells. Am. J. Physiol. 253:C561-C566.

23. Dohlman, J. G., D. G. Payan, and E. J. Goetzl. 1984. Generation of a unique fibroblast-activating factor by human monocytes. Immunology. 52:577584.

24. Greenwood, F., W. Hunter, and J. Glover. 1963. The preparation of ${ }^{131} \mathrm{I}$ labeled human growth hormone of high specific radioactivity. Biochem. J. 89:114123.

25. Bennett, J. P., Jr. 1978. Methods of binding studies. In Neurotransmitter Receptor Binding. H. I. Yamamma, S. J. Enna, and M. J. Kuhar, editors. Raven Press, New York. 71-81.

26. Lennartz, M. R., T. E. Wileman, and P. D. Stahl. 1987. Isolation and characterization of a mannose-specific endocytosis receptor from rabbit alveolar macrophages. Biochem. J. 245:705-711.

27. Laemmli, U. K. 1970. Cleavage of structural proteins during the assembly of the head of bacteriophage $\mathrm{T}_{4}$. Nature (Lond.). 227:680-685.

28. Lennartz, M. R., F. S. Cole, and P. D. Stahl. 1989. Biosynthesis and processing of the mannose receptor in human macrophages. J. Biol. Chem. 264:2385-2390.

29. Mahuran, D., and J. A. Lowden. 1980. The subunit and polypeptide structure of hexosaminidase from human placenta. Can. J. Biochem. 58:287-294.

30. Geiger, B., and R. Arnon. 1976. Purification of hexosaminidase. Methods Enzymol. 50:549-551.

31. Rattazzi, M. C., P. J. Carmody, and R. G. Davidson. 1975. Studies on human lysosomal $\beta$-D- $N$-acetyl hexosaminidase and arylsulfatase isoenzymes. In Isozymes II. Physiological Function. C. L. Markert, editor. Academic Press Inc., San Diego. 439-468.

32. Stephenson, J. D., and V. L. Shepherd. 1987. Purification of the human alveolar macrophage mannose receptor. Biochem. Biophys. Res. Commun. 148:883-889.

33. Harlow, E., and D. Lane, editors. 1988. Antibodies: A Laboratory Manual. Cold Spring Harbor Laboratory, Cold Spring Harbor, NY. 148-238.
34. Pearse, B. M. F., and M. S. Robinson. 1990. Clathrin, adaptors, and sorting. Annu. Rev. Cell Biol. 6:151-171.

35. Chung, K., V. L. Shepherd, and P. D. Stahl. 1984. Swainsonine and castanospermine blockade of mannose glycoprotein uptake by macrophages. $J$. Biol. Chem. 259:14637-14641.

36. Tietze, C., P. Schlesinger, and P. Stahl. 1990. Chloroquine and ammonium ion inhibit receptor-mediated endocytosis of mannose glycoconjugated by macrophages: apparent inhibition of receptor recycling. J. Cell Biol. 93:1-8.

37. Fuh, G., B. C. Cunningham, R. Fukunaga, S. Nagata, D. V. Goeddel, and J. A. Wells. 1992. Rational design of potent antagonists to the human growth hormone receptor. Science (Wash. DC) 256:1677-1680.

38. Valente, W. A., P. Vitti, Z. Yavin, C. M. Rotella, E. F. Grollman, R. S. Toccafondi, and L. D. Kohn. 1982. Monoclonal antibodies to the thyrotropin receptor: stimulating and blocking antibody. Proc. Natl. Acad. Sci. USA. 79:66806684 .

39. Russo, D., G. D. Chazenbalk, Y. Nagayama, H. L. Wadsworth, P. Seto and B. Rapoport. 1991. A new structural model for the thyrotropin receptor as determined by covalent cross-linking of TSH to the recombinant receptor in intact cells: evidence of a single polypeptide chain. Mol. Endocrinol. 5:1607-1612.

40. Nagayama, Y., and B. Rapoport. 1992. The thyrotropin receptor 25 years after its discovery: new insight after its molecular cloning. Mol. Endocrinol. 6:145-156.

41. Kosugi, S., T. Ban, and L. D. Kohn. 1993. Identification of thyroid stimulating antibody-specific interaction sites in the $\mathrm{N}$-terminal region of the thyrotropin receptor. Mol. Endocrinol. 7:114-130.

42. Taylor, M. E., and D. Drickamer. 1993. Structural requirements for high affinity binding of complex ligands by the macrophage mannose receptor. J. Biol. Chem. 268:399-404.

43. Taylor, M. E., K. Bezouska, and K. Drickamer. 1992. Contribution of ligand binding by multiple carbohydrate-recognition domains in the macrophage mannose receptor. J. Biol. Chem. 267:1719-1726.

44. Zanolari, B., S. Raths, B. Singer-Kruier, and H. Riezman. 1992. Yeast pheromone receptor endocytosis and hyperphosphorylation are independent of $\mathrm{G}$ protein-mediated signal transduction. Cell. 71:755-763.

45. Wahl, M. I., S. Nishike, P. Suh, S. G. Rhee, and G. Carpenter. 1989. Epidermal growth factor stimulates tyrosine phosphorylation of phospholipase CII independently of receptor internalization and extracellular calcium. Proc. Natl. Acad. Sci. USA. 86:1568-1572.

46. Lutz, W., and R. Kumar. 1993. Hypertonic sucrose treatment enhances second messenger accumulation in vasopressin-sensitive cells. Am. J. Physiol. 264:F228-F233.

47. Bradley, J. R., D. R. Johnson, and J. S. Pober. 1993. Four different classes of inhibitors of receptor-mediated endocytosis decrease tumor necrosis factorinduced gene expression in human endothelial cells. J. Immunol. 150:5544-5555.

48. Mayorga, L. S., R. Diaz, and P. D. Stahl. 1989. Regulatory role for GTPbinding proteins in endocytosis. Science (Wash. DC). 244:1475-1477.

49. Carter, L. L., T. E. Redelmeier, L. A. Woollenweber, and S. L. Schmid. 1993. Multiple GTP-binding proteins participate in clathrin-coated vesicle-mediated endocytosis. J. Cell. Biol. 120:37-45.

50. Milligan, G. 1993. Mechanisms of multifunctional signalling by $\mathrm{G}$ proteinlinked receptors. TIPS (Trends Pharmacol. Sci.). 14:239-244.

51. Lew, D. B., S. F. Ferguson, and K. U. Malik. 1991. $\beta$-Hexosaminidase stimulated prostaglandin $\mathrm{E}_{2}$ synthesis in bovine tracheal myocytes is mediated via pertussis toxin sensitive GTP-binding regulatory protein. Allergy and Clin. Immunol. News. 1(Suppl.):188. (Abstr.)

52. Lew, D. B., C. Nebigil, and K. U. Malik. 1992. Dual regulation by cAMP of $\beta$-hexosaminidase-induced mitogenesis bovine tracheal myocytes. Am. J. Respir. Cell Mol. Biol. 7:614-619.

53. Lew, D. B., and K. U. Malik. 1992. Mitogenic effect of $\beta$-hexosaminidase on bovine tracheal myocytes is mediated via activation of protein kinase C. FASEB (Fed. Am. Soc. Exp. Biol.) J. 6:A1633. (Abstr.)

54. Lambeau, G., P. Ancian, J. Barhanin, and M. Lazdunski. 1994. Cloning and expression of membrane receptor for secretory phospholipase $\mathrm{A}_{2}$. J. Biol. Chem. 269:1575-1578.

55. Ishizaki, J., K. Hanaski, K. Higashino, J. Kishino, N. Kikuchi, O. Ohara, and $\mathrm{H}$. Arita. 1994. Molecular cloning of pancreatic group I phospholipase $\mathrm{A}_{2}$ receptor. J. Biol. Chem. 269:5897-5904. 